ELORE (ISSN 1456-3010), vol. 20 - 1/2013.

Julkaisija: Suomen Kansantietouden Tutkijain Seura ry.

[http://www.elore.fi/arkisto/1_13/anttonen.pdf]

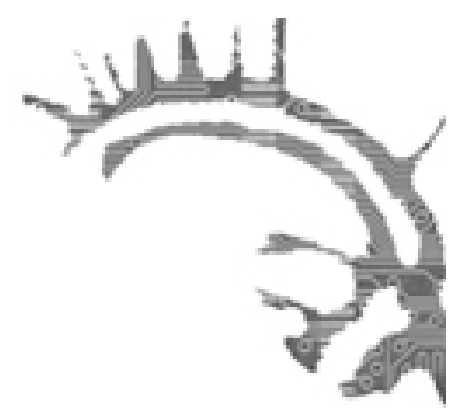

KirJa-ARVio

\title{
HISTORIALLISTEN VÄÄRYYKSIEN ANTEEKSIPYYTÄMISESTÄ
}

\author{
LÖFSTRÖM, JAN (toim.) 2012: Voiko historiaa hyvittää? Historiallisten vä̈ryyksien \\ korjaaminen ja anteeksiantaminen. Helsinki: Gaudeamus. 239 sivua.
}

\section{Marjut Anttonen}

Dosentti Jan Löfströmin toimittamassa Voiko historiaa hyvittää? -kirjassa eri tieteenalojen edustajat pohtivat muun muassa anteeksiantamisen filosofiaa, traumaattisten kokemusten psykologiaa, uhrin oikeutta tuntea kaunaa, katolisen kirkon vaikeuksia pyytää anteeksi kirkossa tehtyjä virheitä sekä nuorten käsityksiä ylisukupolvisesta vastuusta.

Kiinnostus historiallisten vääryyksien käsittelyyn alkoi voimistua kylmän sodan päättymisen jälkeen, ja 2000-luvun taitteesta lähtien lukuisia julkisia anteeksipyyntöjä on esitetty yhtä lailla menneisyyden kuin oman aikamme tapahtumien vuoksi. Esittäjinä ovat yleensä valtiolliset toimijat tai kirkot: presidentit, pääministerit, kirkkojen johtajat, poliisikomentajat, entiset kidutuskeskusten päälliköt ja muut vastaavat toimijat. Julkiset ja institutionaaliset anteeksipyynnöt ovatkin tulleet viime vuosina toistuviksi uutisiksi, ja monien tutkijoiden mukaan elämme jopa "anteeksipyyntöjen aikakautta". Jan Löfström on koonnut ajankohtaisen kirjan johdantolukuun Helsingin Sanomien ja Hufvudstadsbladetin uutisotsikoita vuodelta 2010. Niissä vilisee pahoittelujen laaja kirjo eri puolilta maailmaa: esimerkkeinä ovat muun muassa Japanin anteeksipyyntö EteläKorean miehitysajan julmuuksista ja Serbian parlamentin anteeksipyyntö Srebrenican joukkomurhasta, Britannian anteeksipyynnöt talidomidin uhreilta ja tanskalaislehden anteeksipyyntö Muhammed-pilapiirroksien vuoksi. 
Marjut Anttonen: Historiallisten vääryyksien anteeksipyytämisestä

\section{NÄKÖKULMIA ANTEEKSIANTOON}

Kirjan lukujen otsikot nostavat esiin aihepiirin avainsanat: anteeksianto, anteeksipyyntö, vääryys, hyvittäminen ja politiikka. Otsikkotasolla painottuu anteeksianto, sillä se esiintyy peräti viiden luvun otsikossa, anteeksipyynnöt vain yhdessä. Teksteissä anteeksipyynnöt ja anteeksiannot kietoutuvat ja limittyvät monin tavoin, ja aihetta käsitellään monesta näkökulmasta. Filosofian professori Juha Räikkä luo katsauksen filosofisiin kysymyksiin luvussa "Anteeksianto ja etiikka". Hän pohtii kiinnostavasti myös anteeksipyyntöön liittyvää katumusta ja häpeää sekä esittää lopuksi arvion historiallisen anteeksiannon erityispiirteistä. Yleisen oikeustieteen professori Panu Minkkinen jatkaa filosofista pohdintaa luvussa "Oikeus ja anteeksiannon mahdottomuus". Hän käsittelee kysymystä anteeksiannon vaikeudesta tai suoranaisesta mahdottomuudesta. Ajatuksia herättävä on myös kysymys uhrin oikeudesta kantaa kaunaa ja olla antamatta anteeksi. Minkkinen peräänkuuluttaa oikeuden ja juristin vastuuta näissä kysymyksissä. Luvussa "Poliittisen anteeksiannon rajat ja mahdollisuudet" kansainvälisen politiikan professori Tuomas Forsberg käsittelee anteeksipyyntöjä valtioiden sisäisessä ja niiden välisessä politiikassa. Tässäkin luvussa on ensin laaja pohdinta anteeksiannosta ja sen jälkeen kansainvälisen politiikan esimerkkejä anteeksipyynnöistä. Lopuksi Forsberg tarkastelee sisällissotaa ja talvisotaa menneisyydenhallinnan ja anteeksiantamisen näkökulmasta. Folkloristiikan dosentti, arkistonjohtaja Ulla-Maija Peltonen jatkaa sodan teemoista luvussa "Hauras hyvyys ja anteeksianto sodan muistoissa". Hauras hyvyys tarkoittaa "pieniä tekoja", jotka sisältävät suuria merkityksiä. Peltonen käsittelee niiden ilmenemistä sisällissotaan ja Stalinin ajan terroriin liittyvissä kertomuksissa.

\section{HISTORIALLISTEN HYVITYSTEN TAUSTAA JA NYKYPÄIVÄÄ}

Historiallis-yhteiskuntatiedollisen kasvatuksen professori emerita Sirkka Ahonen ja Jan Löfström käyvät läpi hyvitysten historiaa luvussa "Menneisyyden vääryyksien hyvittäminen - historiallisia päälinjoja”. Heidän mukaansa varhaisinta taustaa edustaa myyttisten näkökulmien arkaainen aikakausi, johon liittyvät vapahduksen, kärsimyksen ja sankaruuden myytit. Seuraavaan, 1900-luvulla alkaneeseen universaalin oikeudenmukaisuuden aikakauteen kuuluvat muun muassa toisen maailmansodan jälkeiset Nürnbergin oikeudenkäynnit sekä vuosisadan loppupuolen totuus- ja sovintokomissiot. Nyt elämme vuosituhannen taitteessa alkanutta kautta, jolloin vääryyden kokemukset muokkaavat identiteettikertomuksia ja erilaiset ryhmittymät esittävät vaatimuksiaan symbolisista hyvityksistä. Omaa tutkimustaan lukiolaisnuorten parissa Löfström esittelee luvussa "Historialliset hyvitykset suomalaisnuorten historiatietoisuudessa". Hän on tehnyt ryhmähaastatteluja kahdeksassa Etelä- ja Itä-Suomen lukiossa ja selvittänyt nuorten käsityksiä historiallisten väröyyksien hyvittämisen mahdollisuudesta. Tekstissä on pitkiä katkelmia nuorten kanssa käydyistä keskusteluista. Löfströmin mukaan lukiolaiset eivät tule helposti ajatelleeksi historiallisiin hyvityksiin liittyviä moninaisia näkökohtia ja tulkintamahdollisuuksia, ja ryhmähaastattelujen tulokset kertovat nuorten historiatietoisuuden hatarista kohdista 
ja katvealueista. Löfström myös ehdottaa ratkaisuja historianopetuksen kehittämiseksi ja oppilaiden historiatietoisuuden vahvistamiseksi.

Näitä tutkimustuloksia lukiessa tuli mieleen, että olisi todella kiinnostava kuulla nyt haastateltujen nuorten mielipiteitä samoista asioista 25-30 vuoden kuluttua. Lukiolaiset ovat vielä kovin nuoria, mutta iän myötä näkemys ja ymmärrys maailmasta, myös vastuun ja syyllisyyden kysymyksistä, alkaa avautua uudenlaisista näkökulmista. Eikö tässä olisi houkutteleva pitkittäistutkimuksen paikka, mikäli se käytännössä olisi mahdollista! Toinen ryhmä, joiden haastattelut olisivat kiinnostavia, ovat poliitikot. Hehän tekevät monesti myös konkreettisia päätöksiä historiaan liittyvien poliittisten anteeksipyyntöjen esittämisestä.

\section{KATOLISEN KIRKON "MUISTIN PUHDISTAMINEN"}

Katolisen kirkon anteeksipyynnöistä kiinnostuneiden kannattaa lukea yleisen kirkkohistorian dosentti, yliopistonlehtori Kimmo Ketolan tiivis katsaus aiheeseen luvussa "Teologian ja politiikan ristipaineissa - katolisen kirkon anteeksipyynnöt". Vanhastaan katolinen kirkko on ollut sitä mieltä, ettei sen tarvitse pyytää anteeksi, mutta suhtautuminen muuttui 1960-luvulla Vatikaanin II konsiilin eli kirkolliskokouksen istuntokaudella. Tuolloin paavi pyysi anteeksi ortodoksisten kirkkojen jäseniltä ja protestanteilta katolisen kirkon osuutta kirkkojen eroon. Konsiili aloitti myös katumustyön suhteessa juutalaisuuteen.

Asenteenmuutosta seurasi katolisen kirkon pyrkimys "puhdistaa" historiallinen muistinsa tunnustamalla vastuunsa virheistään ja vioistaan. Tästä virisi kuitenkin ankara sisäinen kiista siitä, mikä on kirkon ja mikä kirkon jäsenten vastuu teoistaan. Paavi Johannes Paavali II ajoi joka tapauksessa puhdistamiskampanjaa vuosituhannen vaihteen lähestyessä, ja anteeksipyynnön päivänä maaliskuussa 2000 kardinaali Ratzinger esitteli medialle kirkon Muisti ja sovitus-dokumentin. Viisi vuotta myöhemmin Ratzingerista tuli paavi Benedictus XVI, jonka kaudella puhdistamiskampanja joutui entistä suurempiin ongelmiin sitä mukaa kun eri puolilta maailmaa paljastui katolisen papiston pedofiliaskandaaleja. Tämän kirja-arvion kirjoittamisvaiheessa helmikuussa 2013 tuli Vatikaanista uutinen paavi Benedictus XVI:n yllättävästä päätöksestä erota tehtävästään. Uutinen nosti uudelleen esille viime vuosikymmenen skandaalit ja niihin liittyvät oikeusjutut. Nyt kannattaa lukea Ketolan artikkeli, joka selittää katolisen kirkon tilannetta ja antaa tarvittavat taustatiedot Vatikaania hiertävistä suurista ongelmista.

\section{SUOMEN KIRKON ANTEEKSIPYYNTÖÄ EI MAINITA}

Kirkkojen julkiset anteeksipyynnöt ovat lisääntyneet eri puolilla maailmaa viimeksi kuluneen vuosikymmenen aikana. Suomessa tällaiseksi merkkipäiväksi tuli saamelaisten kansallispäivä 6.2.2012, jolloin Oulun hiippakunnan piispa Samuel Salmi pyysi saamelaisilta anteeksi heidän aiempaa alistamistaan ja saamen kieleen kohdistunutta syrjintää. 
Kirkon anteeksipyyntöä edelsi laajahko julkinen keskustelu muun muassa saamelaislasten koulunkäynnistä ja kouluasuntoloista. Tässä keskustelussa nostettiin esiin myös kysymys siitä, pitäisikö valtion pyytää anteeksi saamelaisten kohtelua. Kirkko ehti ensimmäisenä.

Näin huomattavan tapahtuman olisi suonut mahtuvan tähän kirjaan edes parilla lauseella. Esimerkiksi Ahosen ja Löfströmin kirjoittamassa luvussa käsitellään historiallisia hyvityksiä muun muassa vähemmistöryhmien identiteettikysymysten näkökulmasta. Ehkä maininta saamelaisille esitetystä anteeksipyynnöstä olisi sopinut tähän.

Vaikka saamelaiset ovat pohjoismaisessa anteeksipyyntö- ja hyvityskeskustelussa keskeisessä osassa, ei heitä mainita tässä kirjassa lainkaan (lukuun ottamatta yhtä sulkulausetta Jan Löfströmin artikkelissa). Ruotsissa ja Norjassa on käyty jo pitkään monitahoista keskustelua saamelaisten aikaisemmasta asemasta. Esimerkiksi norjalaiset ovat esittäneet anteeksipyyntöjä jo lähes parin vuosikymmenen ajan. Asialla ovat olleet kirkon edustajat, pääministeri ja itse kuningaskin. Lisäksi suurkäräjät teki vuonna 2005 päätöksen laajasta hyvityskorvausjärjestelmästä, jolla valtio pyrkii korvaamaan aikaisempien vuosikymmenien epäoikeudenmukaista kohtelua tietyille ryhmille yhteiskunnassa. Saamelaiset ovat kautta historiansa saaneet kokea tulevansa sivuutetuiksi tai unohdetuiksi, joten olisi ollut toivottavaa, ettei näin olisi käynyt tässä kirjassa.

\section{MiElen PUOLUSTUSKeinot JA Historian haLlinta}

Kulttuuripsykologian sekä aate- ja oppihistorian dosentti, lehtori Juhani Ihanus tarkastelee psyykkisten prosessien merkitystä luvussa "Historialliset vääryydet ja psyykkiset oikaisut". Muistaminen ja poissulkeminen luovat yksilöllisiä ja kollektiivisia historiankuvia ja tarjoavat samalla keinoja vääryyksien korjaamiseksi. Toisaalta vanhoja vääryyksiä oikaisemalla voidaan myös aiheuttaa uusia vär̈ryyksiä. Ihanus käsittelee myös kysymystä yksilöllisestä ja kollektiivisesta muistista sekä muistamisen ja muistelun erilaisista tehtävistä traumojen selvittämisessä. Yhtenä esimerkkinä kollektiiviseen muistamiseen liittyvistä kysymyksistä kirjoittaja tarkastelee ensimmäisen maailmansodan aikaista Armenian kansanmurhaa. Armenian ja Turkin väliset suhteet ovat esillä myös Forsbergin ja Nyyssösen kirjoittamissa luvuissa.

Lopuksi Ihanus haastaa historiantutkijat tarkastelemaan omia vinoutumiaan, sillä lähteitä tulkitessaan tutkijat heijastelevat niissä myös itseään, mieltymyksiään, käsityksiään, uskomuksiaan, asenteitaan ja arvostuksiaan. Historioitsija voi kiintyä tiettyihin lähteisiin ja tukeutua tiettyihin "varmoina" pitämiinsä auktoriteetteihin. Tällä tavoin hän lukitsee historian liittäen siihen aina uudelleen horjumattomina pitämänsä totuudet sen sijaan, että lukisi historiaa kuin avointa kirjaa. Ihanuksen mukaan tutkija voi myös kohdistaa omia tiedostamattomia tunteitaan historian henkilöihin ja siirtyä omassa fantasiassaan heidän rooliinsa; tällä tavoin hän "kontekstualisoi" historian toimijat ja toimet omaksi todellisuudekseen tekstistään. Tästä syystä historiantutkimusta ja -kirjoitusta olisi tarkasteltava myös historioitsijan oman henkilöhistorian ja persoonallisuuden kehityksen ja rakenteen näkökulmasta. 
Marjut Anttonen: Historiallisten vääryyksien anteeksipyytämisestä

\section{MENNEISYYSSUHTEEN ERILAISET POLITISOITUMISET}

Kirjan päättää kansainvälisen politiikan, valtio-opin ja poliittisen historian dosentti, yliopistonlehtori Heino Nyyssösen kirjoittama luku "Jälkisanat: anteeksianto, muistaminen ja unohtaminen”. Nyyssönen kokoaa kirjan teemoja ja valaisee niitä erilaisilla esimerkeillä. Omassa tutkimuksessaan hän on tutkinut Unkarin vuoden 1956 kansannousun käsittelyä maan parlamentissa; hänen mukaansa unkarilaiset ovat kehittäneet useampia erilaisia tapoja käsitellä traagista menneisyyttään.

Yhteenvetona Heino Nyyssönen toteaa, ettei anteeksiannon politiikalle näytä löytyvän yksiselitteistä reseptiä, sillä tiettyjen kulttuuristen eroavaisuuksien lisäksi menneisyyssuhde politisoituu eri tavoin eri maissa. Tämä tulee eri kirjoittajien teksteissä hyvin esille. Voiko historiaa hyvittää? osoittaa kuinka monesta näkökulmasta - niin ajallisesti kuin alueellisestikin - anteeksipyyntöjä ja anteeksiantoa voidaan tarkastella.

Filosofian tohtori, kasvatustieteiden maisteri, dosentti Marjut Anttonen on Turussa asuva tutkija. 